\title{
The microbiome of the built environment and mental health
}

\author{
Andrew J. Hoisington ${ }^{1 *}$, Lisa A. Brenner ${ }^{2}$, Kerry A. Kinney ${ }^{3}$, Teodor T. Postolache ${ }^{4}$ and Christopher A. Lowry ${ }^{5}$
}

\begin{abstract}
The microbiome of the built environment (MoBE) is a relatively new area of study. While some knowledge has been gained regarding impacts of the MoBE on the human microbiome and disease vulnerability, there is little knowledge of the impacts of the MoBE on mental health. Depending on the specific microbial species involved, the transfer of microorganisms from the built environment to occupant's cutaneous or mucosal membranes has the potential to increase or disrupt immunoregulation and/or exaggerate or suppress inflammation. Preclinical evidence highlighting the influence of the microbiota on systemic inflammation supports the assertion that microorganisms, including those originating from the built environment, have the potential to either increase or decrease the risk of inflammation-induced psychiatric conditions and their symptom severity. With advanced understanding of both the ecology of the built environment, and its influence on the human microbiome, it may be possible to develop bioinformed strategies for management of the built environment to promote mental health. Here we present a brief summary of microbiome research in both areas and highlight two interdependencies including the following: (1) effects of the MoBE on the human microbiome and (2) potential opportunities for manipulation of the MoBE in order to improve mental health. In addition, we propose future research directions including strategies for assessment of changes in the microbiome of common areas of built environments shared by multiple human occupants, and associated cohort-level changes in the mental health of those who spend time in the buildings. Overall, our understanding of the fields of both the MoBE and influence of host-associated microorganisms on mental health are advancing at a rapid pace and, if linked, could offer considerable benefit to health and wellness.
\end{abstract}

Keywords: Bioinformed design, Built environment, Disease, Inflammation, Mental health, Microbiome, Neuropsychiatric disease, Psychiatric, Stress

\section{Background}

The influence of the built environment on the mental health of building occupants has been documented including relationships between housing quality, occupant density, noise, indoor air quality, and mental health [1]. One major relationship not yet elucidated is the connection between indoor microorganisms and the mental health of human occupants. Recent advances in DNA sequencing technologies and associated cost savings have led to an expansion of research on microorganisms observed indoors, collectively called the microbiome of the built environment (MoBE). Led in part by the

\footnotetext{
*Correspondence: andrew.hoisington@usafa.edu

1 Department of Civil and Environmental Engineering, US Air Force Academy, 2354 Fairchild Dr. Suite 6H-161, Colorado Springs, CO 80840, USA Full list of author information is available at the end of the article
}

contributions and organization of the Alfred P. Sloan Foundation, building scientists and microbial ecologists are collaborating to (1) investigate the influence of architecture on the MoBE [2, 3], (2) establish a community of cross-disciplinary researchers [4], and (3) develop tools required for data analysis and visualization $[5,6]$. To our knowledge, the MoBE has yet to be evaluated with respect to mental health outcomes.

Preclinical evidence strongly supports the important influence of the human microbiome (e.g., microorganisms localized to the gut, skin, and other organs) on systemic inflammation [7-11], autoimmunity [12], bloodbrain barrier function [13], neuroinflammation [14], cognitive function [15, 16], and emotional behavior [16-19]. Specifically, there is an increasing appreciation regarding the potential association between inflammation and 
mental health, ranging from wellness to neuropsychiatric disease [20-24]. This association is of concern as evidence suggests that chronic inflammatory disorders are increasing in high-income countries. One factor contributing to this increase is thought to be failing immunoregulation, attributable to reduced exposure to the microbial environment within which the mammalian immune system co-evolved [23]. We, along with others, have proposed that faulty immunoregulation is also driving increases in some psychiatric disorders [23, 25-27]. The full development of secondary lymphoid tissues and a diverse lymphocyte repertoire after birth requires signals from microbial components [28], while further microbial signals later in life drive balanced expansion of effector T cell populations [29] and regulatory T cells $[30,31]$. The organisms most responsible for these effects are those with which mammals co-evolved, including the following: (1) the commensal/symbiotic microbiota [30, 31]; (2) certain "old infections," including Helicobacter species, that were present throughout life in evolving human hunter-gatherer populations $[25,32]$; and (3) organisms from the natural environment with which humans were inevitably in daily contact throughout evolution [33-35]. Immunoregulation is compromised in modern high-income settings in part because contact with these three categories of immunoregulatory organisms is reduced [25].

Several society-level shifts, such as those noted below, have and will continue to lead to an increasing disconnect between humans, the outdoor environment, and the microorganisms with which humans co-evolved [36-38]. In the USA, individuals typically spend nearly $90 \%$ of their time in the built environment [39]. Comforts, such as air conditioning, have made geographic locations more hospitable for year-round living in the indoor environment and will likely drive increased time spent in the built environment [40]. Residential homes built in set parcels for subdivisions have an architecture that is typically not conducive to natural heating and cooling. To reduce energy costs, design and subsidized weatherization programs can further reduce outdoor exposures by making the homes less leaky and lowering air exchange rates [41]. This issue may be relevant to developing, as well as developed, countries. Migration from rural to urban environments in developing countries is occurring at a rapid pace [42], and it could lead to a reduction in exposure to environmental microorganisms, as already seen in industrialized nations.

One popular model for conceptualizing the onset of psychiatric disorders is the stress-diathesis model [43, 44]. The model suggests that individuals have biopsychosocial vulnerabilities for developing mental health illnesses (diathesis) that can be realized through stressors. We contend that model has parallels to a model for unhealthy buildings (Fig. 1). That is, an unhealthy building can have design or operational flaws (diathesis) that under specific circumstances (stressors) create a predisposition to poor indoor air quality for the occupants. For example, sick building syndrome is a term used to describe an unhealthy building in which occupants living and working in that space are found to be suffering from acute negative outcomes which are not linked to a specific cause. This article expands upon how the MoBE and mental health fields can and should be integrated. Specifically, we will investigate (1) the effects of the MoBE on the human microbiome and (2) potential opportunities for manipulation of the MoBE in order to improve mental health. In addition, we will propose

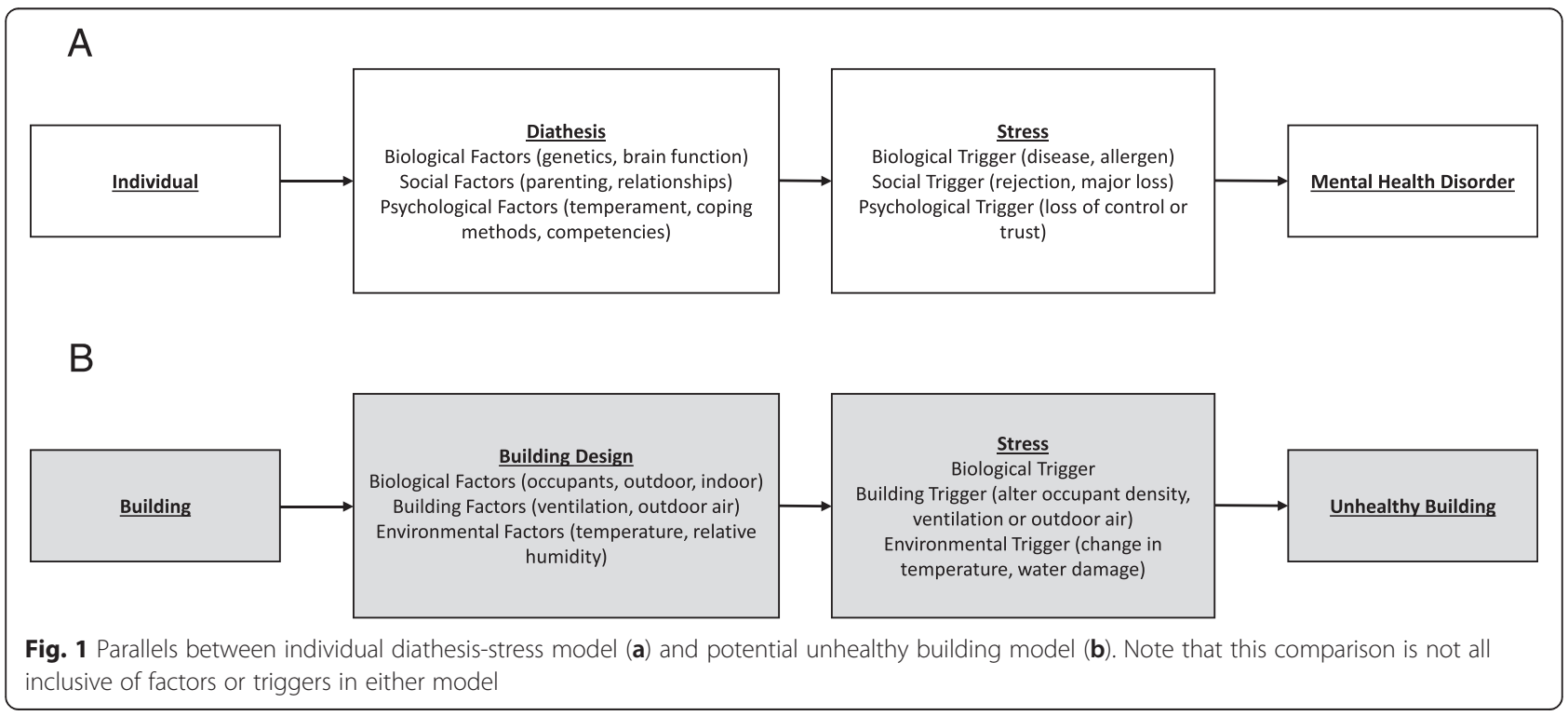


future research directions, including strategies for assessment of changes in the microbiome of common areas of built environments shared by multiple human occupants and associated cohort-level changes in the mental health of those who spend time in the building. The purpose of this review is to initiate discussions that build new research efforts between building scientists, microbial ecologists, and clinical research psychologists and psychiatrists.

\section{Review}

Microbial exposures early in life can have long-lasting impacts on the immune system including reducing inflammatory responses in adulthood [45]. One potential connection between the MoBE and mental health could be the influences of the MoBE on the human microbiome. For that influence to occur, it must be shown that microorganisms in the built environment are transferred to occupants. Researchers have also determined that reciprocal interactions occur between the host immune system and host microbiome. In a murine model, altered immune status, either induced by antagonism of complement component 5a receptor 1 (C5aR) or as observed in immunocompromised mice, was associated with decreases in host-associated skin microbial diversity and altered microbial community structure [46, 47]. Activation of the complement system typically functions as a defense mechanism against invading microorganisms, in part because C5a "primes" phagocytic cells and optimizes innate immune functional responses. Thus, as expected, altering the host immune response to microorganisms alters the host-associated microbial diversity and community structure. With the expansion of the biological field beyond traditional culturing, it is now clear that microbial residue can persist in the environment past a viable cell life [48, 49]. Indeed, microorganisms or microbial antigens, in addition to live, intact microorganisms, are sufficient to have important impacts on systemic immune function and inflammatory disease. For example, heat-killed preparations of mycobacteria have been shown to confer protection in allergy models [50]. In other words, there are reciprocal relationships between the host-associated microbiota and host immune function, and microorganisms do not have to be living, or even intact, in order to have important influences on health outcomes. This may be of interest to MoBE researchers who, to date, have used DNA sequencing that does not distinguish between live, dead but intact, or dead and structurally compromised microorganisms. However, methods using compounds like propidium monoazide (PMA) have shown promise for making these distinctions in qPCR studies [51-53]. Additionally, Kelley and Gilbert [48] suggested mRNA as a sequencing target to distinguish between live and dead microorganisms because RNA is rapidly degraded in the environment.

Current research has focused on how occupants alter the MoBE and have documented the transmission of microorganisms from human occupants to the air and surfaces within buildings [2, 3, 54-59]. Human skin microorganisms are likely a major source of indoor human-related microorganisms and have been observed in the MoBE in classrooms [60], households [57], and athletic environments [55]. The human occupants deposit skin microorganisms at a rate of $10^{6}$ airborne microbial cells per hour [61], but these microorganisms can decay and are replaced at a rapid rate on surfaces commonly in contact with humans [56]. Whereas the cutaneous membrane is completely exposed to the environment [62], mucosal surfaces of the bronchopulmonary system, gastrointestinal system, and genitourinary system each have their own microbiota, with potential for contributions from exposure to microorganisms from the MoBE [63-65]. The skin, mucosal surfaces, and the immune system are in constant communication to promote homeostasis in the human microbiome [11, 66, 67]. Research is sparse on whether these microbial communities, transferred from occupants to the air and surfaces within a building, are conveyed to other occupants. We think it is important to identify whether the existing MoBE can alter the occupants' microbiome and, subsequently, mental health.

Studies that document transmission of microorganisms from reservoirs within the built environment to human occupants have historically focused on pathogens. For instance, nontuberculous mycobacteria (NTM) isolates recovered from water systems and showers have been matched to clinical isolates of NTM $[68,69]$. Similarly, room humidifiers, whirlpools, air conditioning systems, and other sources have been identified as the indoor microbial reservoirs responsible for Legionella infections of human occupants [70-72]. While some indoor sources such as humidifiers provide a direct route of microbial transfer to humans [73, 74], other transfers can be more complex. For instance, in some cases, microorganisms such as Staphylococcus aureus originate from a human source but appear to spend time in an indoor reservoir before being transmitted back to other human occupants [75]. Thus, microorganisms can be transferred to and from occupants and environmental reservoirs within buildings but the level of bidirectional transmission for many microorganisms and microbial communities remains unknown. Of course, transmission of microorganisms from one human occupant to the next is also possible [76, 77], and this further complicates the analysis.

A practical consequence of improved understanding of relationships among the MoBE, host-associated 
microbiota, and mental health could be the development of a bioinformed design in the built environment (see commentary by Green [78]) to prevent negative mental health-related outcomes. This could be analogous to how access to green spaces can improve mental health outcomes [33]. Moreover, studies in rodents suggest that bioimmunomodulatory probiotics (e.g., Lactobacillus reuteri) have stress-protective effects and can reduce negative outcomes of gastrointestinal infections [16]. Preliminary results in mice suggest these probiotics can reduce anxiety and fear following oral or intravenous administration. Building materials or the built environment could be designed to facilitate exposure of human occupants to these types of beneficial probiotics. Probiotics in these instances might extend beyond a few microorganisms and instead include diversity in microbial communities. Microbial diversity has been linked to positive health outcomes, even if the causative agents are not yet delineated [79].

Research on microbial growth on different building materials is now being considered beyond moisturedamaged materials [80-82], but more studies are required to fully evaluate the range of construction practices and building types. The development of such a database of materials that support growth of beneficial microorganisms, in addition to those that support growth of potentially harmful microorganisms, would be of value to the community of researchers. However, to develop that database, knowledge of which microorganisms are beneficial is required. In the context of this review on mental health, we provide a summary in Table 1 of microorganisms that have been linked to positive mental health outcomes. In addition to materials, selection of microorganisms for bio-mediated construction procedures is a relatively new field in the last 10 years and could provide benefits for a bioinformed built environment.

However, as noted by Green, research to date is not yet sufficient to define interactions between microorganisms and the built environment, and the effects that manipulation of the MoBE could have on the occupants. Indeed, only recently have we begun to realize that indiscriminant sterilization of the built environment is not beneficial to occupants [83-85]. The science of either seeding the indoor environment with beneficial microorganisms or providing conditions that promote selective microbial growth is likely a distant reality in practice, and considerable research is required before researchers can recommend such practices. Any modifications would need to consider factors such as geographic location, seasons, building characteristics, occupant ages, health status, and behavior, and likely many other factors yet to be determined. Future work in this direction could provide considerable benefit in terms of mental health wellness. However, as noted by Logan [86], additional adverse environmental factors in urban environments, coined the gray space, could reduce the mental health benefits of changing the MoBE, especially in relation to those individuals who are socioeconomically disadvantaged. An example of an understudied topic is the interaction between the MoBE and the host-associated microbiomes among individuals living or working in close proximity. An initial study of a family observed homogenization of the gut microbiome across family members, at least in comparison to non-family members [87].

Given the importance of inpatient care on mental health, one specific built environment of interest in the relationship between microbiomes of the built environment is that of the hospital. Recently, a collaboration led by the University of Chicago has systematically explored the microbiome in a Chicago hospital from conception through the first year of operation [83]. The results of that work are not yet published, but other articles have identified methods to control microbial spread in a hospital environment including ventilation strategies [88, 89], cleaning techniques [90-92], and use of UV lamps [93-96]. Interestingly, since we do not have a clear understanding of the role of the built environment microbiome on mental health, it is impossible to state if those listed control measures and others are beneficial or harmful to the occupant. Additional research on the influence of the gut and non-gut microbiomes and mental health is required to provide better designs in hospital and treatment centers.

With a better understanding of the interactions between the MoBE and the host-associated microbiota of human occupants, research could proceed to identification of environmental microorganisms that are either beneficial or harmful to the mental health of individuals, thereby mitigating potential diatheses or stressors. Human microbial communities differ across the body, but identification of an individual by their microbial fingerprint can still be achieved through multi-kingdom metagenomics sequencing with an accuracy of over $80 \%$ [62]. Therefore, if certain MoBE markers are determined to contribute to mental health conditions, researchers could use sampling of the built environment to detect potential negative mental health conditions of individuals in that environment. Identification of associations between occupants and the microbiome of their surroundings or personal items, referred to as microbiome fingerprinting, may be possible in the future. Lax et al. [97] utilized a supervised learning algorithm to successfully predict if a 16S rRNA sample was from a phone or a shoe. They sampled at three different geographically separated conferences and were able to predict which conference the samples were from. Another study of 
Table 1 Beneficial microorganisms in mental health studies found in the built environment

Phylum/microorganism Model Environmental sources Presence in MoBE

Mental health relevant findings ${ }^{a}$

\section{Actinobacteria}

Mycobacterium vaccae

Bifidobacterium breve

Bifidobacterium infantis

Bifidobacterium longum

\section{Bacteroidetes}

Bacteroides fragilis

Firmicutes

Clostridium butyricum

Enterococcus faecium

Lactobacillus casei

Lactobacillus fermentum

Lactobacillus helveticus
Human Environmental saprophyte Soil floors [123], reservoirs [125], well water [122, 126], (soil, mud, water, grasses, cooling towers [126, 127], water distribution systems [128], decaying organic matter) household tap water $[126,129]$ moisture-damaged buildMouse [119-125] ing materials [130], terraria [131], sewage [122], drainag

Mouse Human commensal

Rat Human commensal

Human Human commensal

Mouse

Mouse Human commensal

Human Endospore-forming soi bacterium

Mouse Human commensal, wetlands [148]

Human Human commensal, fermented foods [150]

\section{Rat Human commensal, raw} vegetables [154] fermented foods $[150$ ferm

Human Fermented foods [150]

Rat

Mouse

Lactobacillus pentosus
Fermented foods [150] plants [150], office space (Lactobacillus spp.), bathroom pools [132], wastewater treatment plants [133] plants [137]

Human and animal wastewater, wastewater treatment plants [137]

Human wastewater, wastewater treatment plants [137]

Human and animal wastewater, wastewater treatment plants [145]

Increased cognitive function, decreased pain in patients with advanced non-small-cell lung cancer [134]

Activation of brain serotonergic systems and antidepressant-like behavioral effects [135]; decreased anxiety/increased cognitive function [136]

Increased cognitive function [138]; decreased anxietyrelated behaviors [139]

Reversal of depressive-like behavior following maternal separation [140]

Decreased anxiety and depressive symptoms in healthy volunteers (administered with L. helveticus) [141, 142]

Decreased-colitis associated anxiety $[143,144]$; increased cognitive function [138]; decreased stress, anxiety- and depression-related behaviors [139]

Developmental protection from some of the behavioral symptoms associated with autism spectrum disorder [146]

Anxiolytic effects [147]

Well water, human and animal wastewater, wastewater treatment plants [148]

Human and animal wastewater, wastewater treatment surfaces (Lactobacillaceae) [151]

Sewage [155], office space (Lactobacillus spp.) [156], bathroom surfaces (Lactobacillaceae) [151]

Office space (Lactobacillus spp.) [156], bathroom surfaces (Lactobacillaceae) [151]

Increased brain antioxidant markers [149]

Improvement in anxiety symptoms in patients with chronic fatigue syndrome [152]; improved mood [153]

Decreased anxiety and inhibition of antibiotic-induced cognitive impairment [157]

Decreased anxiety and depressive symptoms in health volunteers (administered with B. longum) [141, 142]

Improved cognitive function, decreased anxiety-related behavior [158]; prevention of stress-induced cognitive impairment and anxiety- and depressive-like responses [159]

Decreased anxiety-related behavior [160]; improved cognitive function, decreased anxiety-related behavior (administered with L. rhamnosus) $[15,161]$

Sewage [155], office space (Lactobacillus spp.) [156], Improved cognitive function [162] 
Table 1 Beneficial microorganisms in mental health studies found in the built environment (Continued)

\begin{tabular}{|c|c|c|c|c|}
\hline Lactobacillus reuteri & Human & $\begin{array}{l}\text { Human commensal, } \\
\text { fermented foods [150] }\end{array}$ & $\begin{array}{l}\text { Office space (Lactobacillus spp.) [156], bathroom surfaces } \\
\text { (Lactobacillaceae) [151] }\end{array}$ & Increased workplace healthiness [163] \\
\hline Lactobacillus rhamnosus & Mouse & $\begin{array}{l}\text { Human commensal, } \\
\text { fermented foods [150] }\end{array}$ & $\begin{array}{l}\text { Sewage [155], office space (Lactobacillus spp.) [156], } \\
\text { bathroom surfaces (Lactobacillaceae) [151] }\end{array}$ & $\begin{array}{l}\text { Vagus nerve-dependent alterations in GABA receptor } \\
\text { mRNA expression in brain, reduced anxiety- and } \\
\text { depression-related behavior [17]; improved cognitive } \\
\text { function, decreased anxiety-related behavior (administered } \\
\text { with } L \text {. helveticus) }[161,164]\end{array}$ \\
\hline \multicolumn{5}{|l|}{ Probiotic cocktails } \\
\hline $\begin{array}{l}\text { B. bifidum, B. lactis, L. acidophilus, L. } \\
\text { brevis, L. casei, L. salivarius, L. lactis }\end{array}$ & Human & & & Reduced cognitive reactivity to sad mood [165] \\
\hline $\begin{array}{l}\text { B. animalis subsp. Lactis, Streptococcus } \\
\text { thermophilus, L. bulgaricus, L. Lactis } \\
\text { subsp. Lactis }\end{array}$ & Human & & & $\begin{array}{l}\text { Altered task-related response of brain networks involving } \\
\text { affective, viscerosensory, and somatosensory cortices [166] }\end{array}$ \\
\hline L. acidophilus, B. lactis & Human & & & $\begin{array}{l}\text { Improved scores on anxiety, depression, and stress scales } \\
\text { [167] }\end{array}$ \\
\hline $\begin{array}{l}\text { L. casei, L. acidophilus, L. rhamnosus, L. } \\
\text { bulgaricus, B. breve, B. longum, S. } \\
\text { thermophilus }\end{array}$ & Human & & & $\begin{array}{l}\text { Improved scores on anxiety, depression, and stress scales } \\
\text { [167] }\end{array}$ \\
\hline $\begin{array}{l}\text { VSL\#3: S. salivarius subsp. } \\
\text { thermophilus, B. breve, B. infantis, B. } \\
\text { longum, L. acidophilus, L. planarum, L. } \\
\text { casei, L. delbrueckii subsp. bulgaricus }\end{array}$ & Mouse & & & $\begin{array}{l}\text { Decreased sickness behavior, decreased microglial } \\
\text { activation [168] }\end{array}$ \\
\hline L. plantarum, L. curvatus & Rat & & & Improved cognitive function [169] \\
\hline L. acidophilus, B. lactis, L. fermentum & Rat & & & Improved cognitive function [170] \\
\hline L. helveticus, B. longum & Rat & & & Decreased depressive-like behavior [171] \\
\hline
\end{tabular}

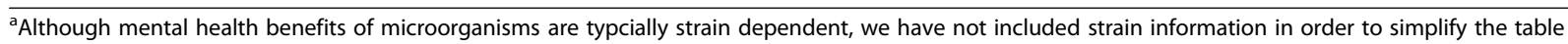


phones sampled the microbiome of both the phones and fingerprints and observed that $82 \%$ of the dominant bacterial sequences was shared between a user and their phone [98]. Using the human microbiome project dataset, by averaging microbiomes over all 18 body sites, and by developing a metagenomic code, Franzosa et al. [99] determined that approximately $30 \%$ of sequences were matched between two sampling events 30 to 300 days apart. The most stable microbiome was the gut, which likely does not significantly contribute to the MoBE outside of restrooms. As noted by that study, research on how the individual microbiomes differ across anatomical sites and longitudinally over time will be crucial for future microbiome fingerprinting efforts.

One important under-recognized contributory role to the MoBE is that of pets. Their microbiome is known to interact with that of their owners. Exposure to pets during childhood has been associated with lower prevalence of allergic disease, potentially through increased petdriven indoor exposure to saprophytic soil organisms with immunomodulatory potential (see Table 1). However, pets also carry indoors microorganisms with potential long-term detrimental effects on mental health. For example, Toxoplasma gondii (T. gondii) is a highly prevalent neurotropic parasite establishing latency in all warm-blooded animals including humans. In immunosuppressed patients and during pregnancy its effects can be devastating. In immunocompetent hosts "latent" $\mathrm{T}$. gondii infection has been associated with mental illness [100] and suicide [101]. Even in individuals with no evidence of mental illness, $T$. gondii seropositivity has been associated with gender-specific trait impulsivity and aggression [102]. Infection with $\mathrm{T}$. gondii occurs via ingestion of tissue bradyzoites from inadequately cooked/ processed meat, or via transmition of oocysts through exposure to cat litter or contaminated soil [103]. Cats, the permanent hosts of $\mathrm{T}$. gondii, are implicated in the direct fecal transmission of the microorganism; pregnant women are advised to avoid exposure to domestic cat litter. Moreover, dogs carry oocysts indoors on their fur by seeking-out and rolling in cat feces and contaminated soil [104].

An extension of microbiome fingerprinting could involve examining the influence of stress on the human microbiome and MoBE. Individuals suffering from psychiatric disorders may have physiological differences that affect the skin [105] and mucosal $[106,107]$ microbiomes, which in turn may alter the MoBE. For example, Biagi et al. [108] found that $9 \%$ of the total variability seen in the gut microbiome was related to proinflammatory cytokines IL-6 and IL-8, with this effect being predominately driven by Proteobacteria. As noted, a feedback loop between occupants, the built environment, and other occupants has been shown in nosocomial infections. That same feedback loop is likely occurring for nonpathogens although not as well studied to date. Nosocomial pathogens like Staphylococcus aureus, Mycobacterium tuberculosis, and Clostridium difficile can remain viable on dry surfaces for months [109, 110], although as already noted, microorganisms do not have to be viable to contribute to health outcomes.

\section{Conclusions}

Despite the massive effort in the human microbiome project, researchers observed that variation in the healthy human microbiome was not well correlated with biometrics (gender, body temperature, blood pressure, etc.) and concluded that other factors might be important [111]. One such factor could be the MoBE that surrounds individuals. It is likely that the MoBE alters immune system function through influences on the host-associated microbiota and, therefore, could have an effect on the mental health of the occupants as presented in Fig. 1. Study designs developed by mental health professionals, building scientists, and microbial ecologists should begin to critically evaluate that idea. Furthermore, given the recent interest in the microbiome-gut-brain axis [112-115], if the MoBE does alters the gut microbiota, considerable research opportunities could follow for future studies of the relationships among the microbiota of the built environment, the host-associated microbiota, and mental health with the aim of intervening to decrease negative health-related outcomes. It is possible that intentional modification of the built environment to increase microbial biodiversity, or to increase exposure to immunoregulatory antigens or probiotics, would result in improved mental health conditions. Moreover, mental health and MoBE studies logically extend to autism spectrum disorders and other neurodevelopmental disorders, such as schizophrenia, that have been investigated with a human microbiome perspective [116-118].

There is credible evidence that these two fields, if linked, could improve future mental health outcomes for both the community at large (e.g., prevention), as well as those with psychiatric disorders (intervention). Research studies will provide the most benefit if discussions among investigators with multiple specialties are initiated in the study design phase. With a combined effort between the MoBE consortia and mental health professionals, a greater understanding of the relationship between the MoBE, the microbiome of human occupants, and mental health can occur at a more rapid pace.

Competing interests

The authors declare that they have no competing interests. 


\section{Authors' contributions}

This research was complete through the collaboration of the Military and Veterans Microbiome Consortium on Research and Education (MVM-CORE). $A J H, L A B, K A K, T T P$, and CAL all contributed equally to this manuscript including the conception, writing, and editing. All authors approved the final manuscript. Additional support was received from the Joint Institute for Food Safety and Applied Nutrition/ University of Maryland through a cooperative agreement with the Food and Drug Administration FDU.001418 (Postolache subaward PI).

The views expressed in this article are those of the authors and do not reflect the official policy or position of the US Air Force, Department of Defense, US Department of Veterans Affairs, US Food and Drug Administration, or the US government.

\section{Author details}

${ }^{1}$ Department of Civil and Environmental Engineering, US Air Force Academy, 2354 Fairchild Dr. Suite 6H-161, Colorado Springs, CO 80840, USA. ${ }^{2}$ Rocky Mountain Mental IIIness Research Education and Clinical Center (MIRECC), University of Colorado Anschutz Medical Campus, 1055 Clermont Street, Denver, CO 80220, USA. ${ }^{3}$ Civil, Architectural and Environmental Engineering, University of Texas Austin, 402 E. Dean Keeton Street, Austin, TX 78712-1085, USA. ${ }^{4}$ University of Maryland School of Medicine, Baltimore MD, Rocky Mountain MIRECC and VISN 5 MIRECC, 685 W. Baltimore Street, Baltimore, MD 21201, USA. ${ }^{5}$ Department of Integrative Physiology and Center for Neuroscience, University of Colorado Boulder, 1725 Pleasant Street, Boulder, CO 80309-0354, USA.

\section{Received: 27 August 2015 Accepted: 29 October 2015 Published online: 17 December 2015}

\section{References}

1. Evans GW. The built environment and mental health. J Urban Health. 2003;80(4):536-55. doi:10.1093/jurban/jtg063.

2. Meadow JF, Altrichter AE, Kembel SW, Kline J, Mhuireach G, Moriyama M, et al. Indoor airborne bacterial communities are influenced by ventilation, occupancy, and outdoor air source. Indoor Air. 2013;24(1):41-8. doi:10.1111/ ina.12047.

3. Kembel SW, Meadow JF, O'Connor TK, Mhuireach G, Northcutt D, Kline J, et al. Architectural design drives the biogeography of indoor bacterial communities. PLoS One. 2014;9(1):e87093. doi:10.1371/journal.pone.0087093.

4. Relman DA, Gilbert JA, Knight R. The promise of the microbiome: function and dysfunction in humans and beyond. Science. 2014;345(6193):226. doi:10.1126/science.345.6193.226-c.

5. Caporaso JG, Lauber CL, Walters WA, Berg-Lyons D, Huntley J, Fierer N, et al. Ultra-high-throughput microbial community analysis on the illumina HiSeq and MiSeq platforms. ISME J. 2012;6(8):1621-4. doi:10.1038/ismej.2012.8.

6. Caporaso JG, Kuczynski J, Stombaugh J, Bittinger K, Bushman FD, Costello EK, et al. QIIME allows analysis of high-throughput community sequencing data. Nat Methods. 2010;7(5):335-6. doi:10.1038/nmeth.f.303.

7. Forsberg A, Abrahamsson TR, Bjorksten B, Jenmalm MC. Pre- and post-natal Lactobacillus reuteri supplementation decreases allergen responsiveness in infancy. Clin Exp Allergy. 2013;43(4):434-42. doi:10.1111/cea.12082.

8. Forsythe P, Inman MD, Bienenstock J. Oral treatment with live lactobacillus reuteri inhibits the allergic airway response in mice. Am J Respir Crit Care Med. 2007;175(6):561-9. doi:10.1164/rccm.200606-8210C.

9. Karimi K, Inman MD, Bienenstock J, Forsythe P. Lactobacillus reuteriinduced regulatory $T$ cells protect against an allergic airway response in mice. Am J Respir Crit Care Med. 2009;179(3):186-93. doi:10.1164/ rccm.200806-9510C.

10. Miniello VL, Brunetti L, Tesse R, Natile M, Armenio L, Francavilla R. Lactobacillus reuteri modulates cytokines production in exhaled breath condensate of children with atopic dermatitis. J Pediatr Gastroenterol Nutr. 2010:50(5):573-6. doi:10.1097/MPG.0b013e3181bb343f.

11. Belkaid Y, Segre JA. Dialogue between skin microbiota and immunity. Science. 2014;346(6212):954-9. doi:10.1126/science.1260144.

12. Horai R, Zárate-Bladés Carlos R, Dillenburg-Pilla P, Chen J, Kielczewski Jennifer L, Silver Phyllis B, et al. Microbiota-dependent activation of an autoreactive $T$ cell receptor provokes autoimmunity in an immunologically privileged site. Immunity. 2015;43(2):343-53. doi:10.1016/ j.immuni.2015.07.014
13. Braniste $\mathrm{V}$, Al-Asmakh M, Kowal C, Anuar F, Abbaspour A, Toth M, et al The gut microbiota influences blood-brain barrier permeability in mice. Sci Transl Med. 2014;6:263. doi:10.1126/scitranslmed.3009759.

14. Lee YK, Menezes JS, Umesaki Y, Mazmanian SK. Proinflammatory T-cell responses to gut microbiota promote experimental autoimmune encephalomyelitis. Proc Natl Acad Sci U S A. 2011;108:4615-22. doi:10.1073/ pnas.1000082107.

15. Gareau MG. Microbiota-gut-brain axis and cognitive function. In: Lyte M, Cryan JF, editors. Microbial endocrinology: the microbiota-gut-brain axis in health and disease. advances in experimental medicine and biology. 2014. p. 357-71.

16. Smith CJ, Emge JR, Berzins $K$, Lung L, Khamishon R, Shah P, et al. Probiotics normalize the gut-brain-microbiota axis in immunodeficient mice. Am J Physiol Gastrointest Liver Physiol. 2014;307(8):G793-802. doi:10.1152/ ajpgi.00238.2014.

17. Bravo JA, Forsythe P, Chew MV, Escaravage E, Savignac HM, Dinan TG, et al. Ingestion of Lactobacillus strain regulates emotional behavior and central GABA receptor expression in a mouse via the vagus nerve. Proc Natl Acad Sci U S A. 2011;108(38):16050-5. doi:10.1073/pnas.1102999108.

18. Neufeld KM, Kang N, Bienenstock J, Foster JA. Reduced anxiety-like behavior and central neurochemical change in germ-free mice. Neurogastroenterol Motil. 2011;23:3. doi:10.1111/j.1365-2982.2010.01620.x.

19. Heijtza RD, Wang SG, Anuar F, Qian Y, Bjorkholm B, Samuelsson A, et al. Normal gut microbiota modulates brain development and behavior. Proc Natl Acad Sci U S A. 2011;108(7):3047-52. doi:10.1073/ pnas.1010529108

20. Felger JC, Lotrich FE. Inflammatory cytokines in depression: nuerobiological mechanisms and therapeutic implications. Neuroscience. 2013;246:199-229. doi:10.1016/j.neuroscience.2013.04.060

21. Haroon E, Raison CL, Miller AH. Psychoneuroimmunology meets neuropsychopharmacology: translational implications of the impact of inflammation on behavior. Neuropsychopharmacology. 2012;37(1):137-62. doi:10.1038/npp.2011.205.

22. Miller $\mathrm{AH}$, Raison $\mathrm{CL}$. Are anti-inflammatory therapies viable treatments for psychiatric disorders? Where the rubber meets the road. JAMA Psychiatry. 2015;72(6):527-8. doi:10.1001/jamapsychiatry.2015.22.

23. Raison CL, Lowry CA, Rook GAW. Inflammation, sanitation, and consternation loss of contact with coevolved, tolerogenic microorganisms and the pathophysiology and treatment of major depression. Arch Gen Psychiatry. 2010;67(12):1211-24. doi:10.1001/archgenpsychiatry.2010.161.

24. Rook GAW, Raison CL, Lowry CA. Childhood microbial experience, immunoregulation, inflammation and adult susceptibility to psychosocial stressors and depression in rich and poor countries. Evol Med Public Health. 2013;2013(1):14-7. doi:10.1093/emph/eos005.

25. Rook GA, Raison CL, Lowry CA. Microbial 'old friends', immunoregulation and socioeconomic status. Clin Exp Immunol. 2014;177(1):1-12.

26. Rook GAW, Raison CL, Lowry CA. Microbiota, immunoregulatory old friends and psychiatric disorders. In: Lyte M, Cryan JF, editors. microbial endocrinology: the microbiota-gut-brain axis in health and disease. Advances in experimental medicine and biology. 2014. p. 319-56.

27. Rook GAW, Lowry CA. The hygiene hypothesis and psychiatric disorders. Trends Immunol. 2008;29(4):150-8. doi:10.1016/j.it.2008.01.002.

28. McFall-Ngai M, Hadfield MG, Bosch TCG, Carey HV, Domazet-Loso T, Douglas AE, et al. Animals in a bacterial world, a new imperative for the life sciences. Proc Natl Acad Sci U S A. 2013;110(9):3229-36. doi:10.1073/ pnas. 1218525110.

29. Gaboriau-Routhiau V, Rakotobe S, Lecuyer E, Mulder I, Lan A, Bridonneau C, et al. The key role of segmented filamentous bacteria in the coordinated maturation of gut helper T cell responses. Immunity. 2009;31(4):677-89. doi:10.1016/j.immuni.2009.08.020.

30. Atarashi K, Tanoue T, Shima T, Imaoka A, Kuwahara T, Momose Y, et al. Induction of colonic regulatory $T$ cells by indigenous clostridium species Science. 2011;331(6015):337-41. doi:10.1126/science.1198469.

31. Round JL, Mazmanian SK. Inducible foxp(3+) regulatory T-cell development by a commensal bacterium of the intestinal microbiota. Proc Natl Acad Sci U S A. 2010;107(27):12204-9. doi:10.1073/pnas.0909122107.

32. Wolfe ND, Dunavan CP, Diamond J. Origins of major human infectious diseases. Nature. 2007;447(7142):279-83. doi:10.1038/nature05775.

33. Rook GA. Regulation of the immune system by biodiversity from the natural environment: an ecosystem service essential to health. Proc Natl Acad Sci U S A. 2013;110(46):18360-7. 
34. Ege MJ, Mayer M, Normand AC, Genuneit J, Cookson W, Braun-Fahrlander C, et al. Exposure to environmental microorganisms and childhood asthma. N Engl J Med. 2011;364(8):701-9. doi:10.1056/NEJMoa1007302.

35. Hanski I, von Hertzen L, Fyhrquist N, Koskinen K, Torppa K, Laatikainen T, et al. Environmental biodiversity, human microbiota, and allergy are interrelated. Proc Natl Acad Sci U S A. 2012;109(21):8334-9. doi:10.1073/ pnas.1205624109.

36. Clemente JC, Pehrsson EC, Blaser MJ, Sandhu K, Gao Z, Wang B, et al. The microbiome of uncontacted Amerindians. Sci Adv. 2015;1:3.

37. Martinez I, Stegen JC, Maldonado-Gomez MX, Eren AM, Siba PM, Greenhill $A R$, et al. The gut microbiota of rural Papua New Guineans: composition, diversity patterns, and ecological processes. Cell Rep. 2015;11(4):527-38. doi:10.1016/j.celrep.2015.03.049.

38. Martin LJ, Adams RL, Bateman A, Bik HM, Hawks J, Hird SM, et al. Evolution of the indoor biome. Trends Ecol Evol. 2015;30(4):223-32. doi:10.1016/ j.tree.2015.02.001.

39. Klepeis NTA, Behar JV. Analysis of the National Human Activity Pattern Survey (NHAPS) respondents from a standpoint of exposure assessment. Las Vegas: Laboratory USEPANER; 1996.

40. Weschler CJ. Changes in indoor pollutants since the 1950s. Atmos Environ 2009:43(1):153-69. doi:10.1016/j.atmosenv.2008.09.044.

41. Cautley D, Viner J, Lord M, Pearce M. Test methods and protocols for environmental and safety hazards associated with home energy retrofits. Golden: US Department of Energy, Energy Efficiency \& Renewable Energy, Building Technologies Program; 2012.

42. Sanders D. Arrival city. New York: Random House; 2012.

43. Meehl PE. Schizotaxia, schizotypy, schizophrenia. Am Psychol. 1962;17(12):827.

44. Rosenthal D. Genetic theory and abnormal behavior. New York: McGraw-Hill; 1970.

45. McDade TW, Rutherford J, Adair L, Kuzawa CW. Early origins of inflammation: microbial exposures in infancy predict lower levels of Creactive protein in adulthood. Proc Biol Sci. 2010;277(1684):1129-37. doi:10.1098/rspb.2009.1795

46. Chehoud C, Rafail S, Tyldsley AS, Seykora JT, Lambris JD, Grice EA. Complement modulates the cutaneous microbiome and inflammatory milieu. Proc Natl Acad Sci. 2013;110(37):15061-6. doi:10.1073/ pnas.1307855110.

47. Garcia-Garcera M, Coscolla M, Garcia-Etxebarria K, Martin-Caballero J, Gonzalez-Candelas F, Latorre A, et al. Staphylococcus prevails in the skin microbiota of long-term immunodeficient mice. Environ Microbiol. 2012;14(8):2087-98. doi:10.1111/j.1462-2920.2012.02756.x.

48. Kelley ST, Gilbert JA. Studying the microbiology of the indoor environment. Genome Biol. 2013;14:2. doi:10.1186/gb-2013-14-2-202.

49. Nielsen KM, Johnsen PJ, Bensasson D, Daffonchio D. Release and persistence of extracellular DNA in the environment. Environ Biosafety Res. 2007:6(1-2):37-53.

50. Hunt JR, Martinelli R, Adams VC, Rook GA, Brunet LR. Intragastric administration of Mycobacterium vaccae inhibits severe pulmonary allergic inflammation in a mouse model. Clin Exp Allergy. 2005;35(5):685-90.

51. Nocker A, Sossa KE, Camper AK. Molecular monitoring of disinfection efficacy using propidium monoazide in combination with quantitative PCR. J Microbiol Methods. 2007;70(2):252-60. doi:10.1016/j.mimet.2007.04.014.

52. Nocker A, Sossa-Fernandez P, Burr MD, Camper AK. Use of propidium monoazide for live/dead distinction in microbial ecology. Appl Environ Microbiol. 2007:73(16):5111-7. doi:10.1128/AEM.02987-06.

53. Exterkate RAM, Zaura E, Brandt BW, Buijs MJ, Koopman J, Crielaard W, et al. The effect of propidium monoazide treatment on the measured bacterial composition of clinical samples after the use of a mouthwash. Clin Oral Investig. 2015;19(4):813-22. doi:10.1007/s00784-014-1297-z.

54. Ramos T, Dedesko S, Siegel JA, Gilbert JA, Stephens B. Spatial and tempora variations in indoor environmental conditions, human occupancy, and operational characteristics in a new hospital building. PLoS One. 2015;10:3. doi:10.1371/journal.pone.0118207.

55. Wood M, Gibbons S, Lax S, Eshoo-Anton T, Owens S, Kennedy S, et al. Athletic equipment microbiota are shaped by interactions with human skin. Microbiome. 2015:3(1):25. doi:10.1186/s40168-015-0088-3.

56. Lax S, Nagler CR, Gilbert JA. Our interface with the built environment: immunity and the indoor microbiota. Trends Immunol. 2015;36(3):121-3. doi:10.1016/j.it.2015.01.001.

57. Lax S, Smith DP, Hampton-Marcell J, Owens SM, Handley KM, Scott NM, et al. Longitudinal analysis of microbial interaction between humans and the indoor environment. Science. 2014;345(6200):1048-52. doi:10.1126/ science.1254529.

58. Flores GE, Bates ST, Caporaso JG, Lauber CL, Leff JW, Knight R, et al. Diversity, distribution and sources of bacteria in residential kitchens. Environ Microbiol. 2013;15(2):588-96. doi:10.1111/1462-2920.12036.

59. Brauer SL, Vuono D, Carmichael MJ, Pepe-Ranney C, Strom A, Rabinowitz E, et al. Microbial sequencing analyses suggest the presence of a fecal veneer on indoor climbing wall holds. Curr Microbiol. 2014;69(5):681-9. doi:10.1007/ s00284-014-0643-3.

60. Hospodsky D, Qian J, Nazaroff WW, Yamamoto N, Bibby K, Rismani-Yazdi H, et al. Human occupancy as a source of indoor airborne bacteria. PLoS One. 2012;7(4):e34867. doi:10.1371/journal.pone.0034867.

61. Qian J, Hospodsky D, Yamamoto N, Nazaroff WW, Peccia J. Size-resolved emission rates of airborne bacteria and fungi in an occupied classroom. Indoor Air. 2012;22:339-51. doi:10.1111/j.1600-0668.2012.00769.x.

62. Oh J, Byrd AL, Deming C, Conlan S, Program NCS, Kong HH, et al. Biogeography and individuality shape function in the human skin metagenome. Nature. 2014;514(7520):59-64. doi:10.1038/nature13786.

63. Moore MN. Do airborne biogenic chemicals interact with the PI3K/Akt/ mTOR cell signalling pathway to benefit human health and wellbeing in rural and coastal environments? Environ Res. 2015;140:65-75. doi:10.1016/ j.envres.2015.03.015.

64. Panzer AR, Lynch SV. Influence and effect of the human microbiome in allergy and asthma. Curr Opin Rheumatol. 2015;27(4):373-80. doi:10.1097/ BOR.0000000000000191.

65. Fujimura KE, Lynch SV. Microbiota in allergy and asthma and the emerging relationship with the gut microbiome. Cell Host Microbe. 2015;17(5):592602. doi:10.1016/j.chom.2015.04.00.

66. Sanford JA, Gallo RL. Functions of the skin microbiota in health and disease. Semin Immunol. 2013;25(5):370-7. doi:10.1016/j.smim.2013.09.005.

67. SanMiguel A, Grice E. Interactions between host factors and the skin microbiome. Cell Mol Life Sci. 2015;72(8):1499-515. doi:10.1007/s00018-0141812-z.

68. Halstrom S, Price $P$, Thomson R. Review: environmental mycobacteria as a cause of human infection. Int J Mycobacteriol. 2015;4(2):81-91. doi:10.1016/ j.jimyco.2015.03.002.

69. Thomson R, Tolson C, Carter R, Coulter C, Huygens F, Hargreaves M. Isolation of nontuberculous mycobacteria (NTM) from household water and shower aerosols in patients with pulmonary disease caused by NTM. J Clin Microbiol. 2013;51(9):3006-11. doi:10.1128/jcm.00899-13.

70. van Heijnsbergen E, Schalk JAC, Euser SM, Brandsema PS, den Boer JW Husman AMD. Confirmed and potential sources of Legionella reviewed. Environ Sci Technol. 2015:49(8):4797-815. doi:10.1021/acs.est.5b00142.

71. Tyndall RL, Lehman ES, Bowman EK, Milton DK, Barbaree JM. Home humidifiers as a potential source of exposure to microbial pathogens, endotoxins, and allergens. Indoor Air Int J Indoor Air Qual Clim. 1995;5(3):171-8. doi:10.1111/j.1600-0668.1995.t01-1-00003.x.

72. Krogulska B, Matuszewska R, Krogulski A, Szczotko M, Bartosik M, Maziarka D, et al. Occurrence of Legionella in technological water and studies of the total number of bacteria and fungi in indoor air at workplaces where water aerosol is generated. Med Pr. 2014;65(3):325-34.

73. Hull NM, Reens AL, Robertson CE, Stanish LF, Harris JK, Stevens MJ, et al. Molecular analysis of single room humidifier bacteriology. Water Res. 2015;69:318-27. doi:10.1016/j.watres.2014.11.024.

74. Lee $\mathrm{JH}, \mathrm{Ahn} \mathrm{KH}, \mathrm{Yu}$ IJ. Outbreak of bioaerosols with continuous use of humidifier in apartment room. Toxicol Res. 2012;28(2):103-6. doi:10.5487/tr.2012.28.2.103.

75. Uhlemann AC, Dordel J, Knox JR, Raven KE, Parkhill J, Holden MTG, et al. Molecular tracing of the emergence, diversification, and transmission of S. aureus sequence type 8 in a New York community. Proc Natl Acad Sci U S A. 2014;111(18):6738-43. doi:10.1073/pnas.1401006111.

76. Tran K, Cimon K, Severn M, Pessoa-Silva CL, Conly J. Aerosol generating procedures and risk of transmission of acute respiratory infections to healthcare workers: a systematic review. PLoS One. 2012;7(4):e35797. doi:10.1371/journal.pone.0035797.

77. Bhatt S, Gething PW, Brady OJ, Messina JP, Farlow AW, Moyes CL, et al. The global distribution and burden of dengue. Nature. 2013:496(7446):504-7. doi:10.1038/nature12060.

78. Green JL. Can bioinformed design promote healthy indoor ecosystems? Indoor Air. 2014;24(2):113-5. doi:10.1111/ina.12090.

79. Legatzki A, Rosler B, von Mutius E. Microbiome diversity and asthma and allergy risk. Curr Allergy Asthma Rep. 2014;14:10. doi:10.1007/s11882-014-0466-0. 
80. Hoang CP, Kinney KA, Corsi RL, Szaniszlo PJ. Resistance of green building materials to fungal growth. Int Biodeter Biodegr. 2010;64(2):104-13. doi:10.1016/j.ibiod.2009.11.001.

81. Grant C, Hunter CA, Flannigan B, Bravery AF. The moisture requirements of moulds isolated from domestic dwellings. Int Biodeterior. 1989;25(4):259-84. doi:10.1016/0265-3036(89)90002-x.

82. Verdier T, Coutand M, Bertron A, Roques C. A review of indoor microbial growth across building materials and sampling and analysis methods. Build Environ. 2014;80:136-49. doi:10.1016/j.buildenv.2014.05.030.

83. Arnold C. Rethinking sterile: the hospital microbiome. Environ Health Perspect. 2014;122(7):A182-7. doi:10.1289/ehp.122-A182.

84. Lax S, Gilbert JA. Hospital-associated microbiota and implications for nosocomial infections. Trends Mol Med. 2015;21(7):427-32. doi:10.1016/j.molmed.2015.03.005.

85. Kembel SW, Jones E, Kline J, Northcutt D, Stenson J, Womack AM, et al. Architectural design influences the diversity and structure of the built environment microbiome. ISME J. 2012;1-11. doi:10.1038/ismej.2011.211.

86. Logan AC. Dysbiotic drift: mental health, environmental grey space, and microbiota. J Physiol Anthropol. 2015;34(1):015-0061.

87. Schloss P, Iverson K, Petrosino J, Schloss S. The dynamics of a family's gut microbiota reveal variations on a theme. Microbiome. 2014;2(1):25. doi:10.1186/2049-2618-2-25.

88. Napoli C, Marcotrigiano V, Montagna MT. Air sampling procedures to evaluate microbial contamination: a comparison between active and passive methods in operating theatres. BMC Public Health. 2012;12:594. doi:10.1186/1471-2458-12-594.

89. Chuaybamroong P, Choomseer P, Sribenjalux P. Comparison between hospital single air unit and central air unit for ventilation performances and airborne microbes. Aerosol Air Qual Res. 2008;8(1):28-36.

90. French GL, Otter JA, Shannon KP, Adams NMT, Watling D, Parks MJ. Tackling contamination of the hospital environment by methicillin-resistant Staphylococcus aureus (MRSA): a comparison between conventional terminal cleaning and hydrogen peroxide vapour decontamination. J Hosp Infect. 2004;57(1):31-7. doi:10.1016/j.jhin.2004.03.006.

91. Rutala WA, Weber DJ. Uses of inorganic hypochlorite (bleach) in health-care facilities. Clin Microbiol Rev. 1997;10(4):597-610.

92. Vandini A, Temmerman R, Frabetti A, Caselli E, Antonioli P, Balboni PG, et al. Hard surface biocontrol in hospitals using microbial-based cleaning products. PLoS One. 2014;9:9. doi:10.1371/journal.pone.0108598.

93. Chang CW, Li SY, Huang SH, Huang CK, Chen YY, Chen CC. Effects of ultraviolet germicidal irradiation and swirling motion on airborne Staphylococcus aureus, Pseudomonas aeruginosa and Legionella pneumophila under various relative humidities. Indoor Air. 2013;23(1):74-84. doi:10.1111/j.1600-0668.2012.00793.x.

94. Mphaphlele M, Dharmadhikari AS, Jensen PA, Rudnick SN, van Reenen TH, Pagano MA, et al. Institutional tuberculosis transmission controlled trial of upper room ultraviolet air disinfection: a basis for new dosing guidelines. Am J Respir Crit Care Med. 2015;192(4):477-84. doi:10.1164/rccm.201501-00600C

95. Hones K, Stangl F, Sift M, Hessling M. Visible optical radiation generates bactericidal effect applicable for inactivation of health care associated germs demonstrated by inactivation of E. coli and B. subtilis using $405 \mathrm{~nm}$ and $460 \mathrm{~nm}$ light emitting diodes. Novel Biophotonics Techn Appl III. 2015;9540. doi:10.1117/12.2183903.

96. Miller SL. Upper room germicidal ultraviolet systems for air disinfection are ready for wide implementation. Am J Respir Crit Care Med. 2015;192(4):407-9. doi:10.1164/rccm.201505-0927ED.

97. Lax S, Hampton-Marcell J, Gibbons S, Colares G, Smith D, Eisen J, et al. Forensic analysis of the microbiome of phones and shoes. Microbiome. 2015;3(1):21. doi:10.1186/s40168-015-0082-9.

98. Meadow JF, Altrichter AE, Green JL. Mobile phones carry the personal microbiome of their owners. PeerJ. 2014;24:2. doi:10.7717/peerj.447.

99. Franzosa EA, Huang K, Meadow JF, Gevers D, Lemon KP, Bohannan BJM, et al. Identifying personal microbiomes using metagenomic codes. Proc Natl Acad Sci. 2015;112(22):E2930-8. doi:10.1073/ pnas. 1423854112

100. Fond G, Kuin A, Koeter MW, Lutter R, van Gool T, Yolken R, et al. Beyond the association. Toxoplasma gondii in schizophrenia, bipolar disorder, and addiction: systematic review and meta-analysis. Acta Psychiatr Scand. 2015;132(3):161-79. doi:10.1111/acps.12423.

101. Pedersen MG, Mortensen PB, Norgaard-Pedersen B, Postolache TT. Toxoplasma gondii infection and self-directed violence in mothers. Arch Gen Psychiatry. 2012;69(11):1123-30. PubMed PMID: 22752117.
102. Cook TB, Brenner LA, Cloninger CR, Langenberg P, Igbide A, Giegling I, et al. "Latent" infection with Toxoplasma gondii: association with trait aggression and impulsivity in healthy adults. J Psychiatr Res. 2015;60:87-94. doi:10.1016/j.jpsychires.2014.09.019. Epub 2014 Sep 28. PubMed PMID: 25306262.

103. Jones JL, Kruszon-Moran D, Rivera HN, Price C, Wilkins PP. Toxoplasma gondii seroprevalence in the United States 2009-2010 and comparison with the past two decades. Am J Trop Med Hyg. 2014;90(6):1135-9. doi:10.4269/ ajtmh.14-0013.

104. Frenkel JK, Lindsay DS, Parker BB, Dobesh M. Dogs as possible mechanical carriers of Toxoplasma, and their fur as a source of infection of young children. Int J Infect Dis. 2003;7(4):292-3.

105. Holmes CJ, Plichta JK, Gamelli RL, Radek KA. Dynamic role of host stress responses in modulating the cutaneous microbiome: implications for wound healing and infection. Adv Wound Care. 2015;4(1):24-37. doi:10.1089/wound.2014.0546.

106. Schmidt C. Mental health: thinking from the gut. Nature. 2015;518(7540):S12-5. doi:10.1038/518S13a.

107. Clarke G, O'Mahony S, Dinan T, Cryan J. Priming for health: gut microbiota acquired in early life regulates physiology, brain and behaviour. Acta Paediatr. 2014;103(8):812-9. doi:10.1111/apa.12674.

108. Biagi E, Nylund L, Candela M, Ostan R, Bucci L, Pini E, et al. Through ageing, and beyond: gut microbiota and inflammatory status in seniors and centenarians. PLoS One. 2010;5(5):e10667. doi:10.1371/journal.pone.0010667.

109. Kampf G, Kramer A. Epidemiologic background of hand hygiene and evaluation of the most important agents for scrubs and rubs. Clin Microbiol Rev. 2004;17(4):863-93. doi:10.1128/cmr.17.4.863-893.2004.

110. Kramer M, Obermajer N, Bogovic Matijasic B, Rogelj I, Kmetec V. Quantification of live and dead probiotic bacteria in lyophilised product by real-time PCR and by flow cytometry. Appl Microbiol Biotechnol. 2009;84(6):1137-47. doi:10.1007/s00253-009-2068-7.

111. Consortium THMP. Structure, function and diversity of the healthy human microbiome. Nature. 2012;486(7402):207-14. doi:10.1038/nature11234.

112. Foster JA, McVey Neufeld K-A. Gut-brain axis: how the microbiome influences anxiety and depression. Trends Neurosci. 2013;36(5):305-12. doi:10.1016/j.tins.2013.01.005.

113. Petra Al, Panagiotidou S, Hatziagelaki E, Stewart JM, Conti P, Theoharides TC. Gut-microbiota-brain axis and its effect on neuropsychiatric disorders with suspected immune dysregulation. Clin Ther. 2015;37(5):984-95. doi:10.1016/ j.clinthera.2015.04.002.

114. Luna RA, Foster JA. Gut brain axis: diet microbiota interactions and implications for modulation of anxiety and depression. Curr Opin Biotechnol. 2015;32:35-41. doi:10.1016/j.copbio.2014.10.007.

115. Cryan JF, Dinan TG. Mind-altering microorganisms: the impact of the gut microbiota on brain and behaviour. Nat Rev Neurosci. 2012;13(10):701-12. doi:10.1038/nrn3346.

116. Bilbo SD, Nevison CD, Parker W. A model for the induction of autism in the ecosystem of the human body: the anatomy of a modern pandemic? Microb Ecol Health Dis. 2015;26:26253. doi:10.3402/mehd.v26.26253.

117. Toh MC, Allen-Vercoe E. The human gut microbiota with reference to autism spectrum disorder: considering the whole as more than a sum of its parts. Microb Ecol Health Dis. 2015;26:26309. doi:10.3402/mehd.v26.26309.

118. Krajmalnik-Brown R, Lozupone C, Kang DW, Adams JB. Gut bacteria in children with autism spectrum disorders: challenges and promise of studying how a complex community influences a complex disease. Microb Ecol Health Dis. 2015;26:26914. doi:10.3402/mehd.v26.26914.

119. Collins CH, Grange JM, Yates MD. Mycobacteria in water. J Appl Bacteriol. 1984;57(2):193-211. doi:10.1111/j.1365-2672.1984.tb01384.x.

120. Stanford J, Paul R. A preliminary report on some studies of environmental mycobacteria from Uganda. Ann Soc Belg Med Trop. 1973;53:389-93.

121. Primm TP, Lucero CA, Falkinham JO. Health impacts of environmental mycobacteria. Clin Microbiol Rev. 2004;17(1):98-106. doi:10.1128/ cmr.17.1.98-106.2004.

122. Jin BW, Saito H, Yoshii Z. Environmental mycobacteria in Korea. Microbiol Immunol. 1984;28(6):667-77. doi:10.1111/j.1348-0421.1984.tb00721.x.

123. Pontiroli A, Khera TT, Oakley BB, Mason S, Dowd SE, Travis ER, et al. Prospecting environmental mycobacteria: combined molecular approaches reveal unprecedented diversity. PLoS One. 2013;8(7):e68648. doi:10.1371/ journal.pone.0068648.

124. Gcebe N, Rutten V, Gey van Pittius NC, Michel A. Prevalence and distribution of non-tuberculous mycobacteria (NTM) in cattle, African 
buffaloes (Syncerus caffer) and their environments in South Africa. Transbound Emerg Dis. 2013;60:74-84. doi:10.1111/tbed.12133.

125. Kamala T, Paramasivan CN, Herbert D, Venkatesan P, Prabhakar R. Isolation and identification of environmental mycobacteria in the mycobacterium bovis BCG trial area of south India. Appl Environ Microbiol. 1994;60(6):2180-3.

126. Kamala T, Paramasivan CN, Herbert D, Venkatesan P, Prabhakar R. Evaluation of procedures for isolation of nontuberculous mycobacteria from soil and water. Appl Environ Microbiol. 1994;60(3):1021-4.

127. Adrados B, Julián E, Codony F, Torrents E, Luquin M, Morató J. Prevalence and concentration of non-tuberculous mycobacteria in cooling towers by means of quantitative PCR: a prospective study. Curr Microbiol. 2011;62(1):313-9. doi:10.1007/s00284-010-9706-2.

128. Pryor M, Springthorpe S, Riffard S, Brooks T, Huo Y, Davis G, et al. Investigation of opportunistic pathogens in municipal drinking water under different supply and treatment regimes. Water Sci Technol. 2004;50(1):83-90.

129. van Ingen J, Blaak H, de Beer J, de Roda Husman AM, van Soolingen D. Rapidly growing nontuberculous mycobacteria cultured from home tap and shower water. Appl Environ Microbiol. 2010;76(17):6017-9. doi:10.1128/ aem.00843-10.

130. Torvinen E, Meklin T, Torkko P, Suomalainen S, Reiman M, Katila M-L, et al. Mycobacteria and fungi in moisture-damaged building materials. Appl Environ Microbiol. 2006;72(10):6822-4. doi:10.1128/aem.00588-06.

131. Sussland Z, Prochazkva V. Atypical mycobacteria isolated from terrarium from zoological garden in Prague. Veterinarstvi (in Czech). 1975;25:320-2.

132. Lavania M, Katoch K, Parashar D, Sharma P, Das R, Chauhan D, et al. 2 predominance of Mycobacterium fortuitum-chelonae complex in Ghatampur field area, endemic for leprosy. Indian J Lepr. 2008;80(4):323.

133. Hernández AS, Torres MG, Molina JA, Amat GC. Biodegradation potential and molecular detection of the cathecol 1, 2-dioxygenase gene of actinobacteria isolated from wastewater treatment plants in Spain. Microbes in applied research: current advances and challenges. Singapore: World Scientific Publishing Co; 2015.

134. O'Brien MER, Anderson H, Kaukel E, O'Byrne K, Pawlicki M, von Pawel J, et al. SRL172 (killed Mycobacterium vaccae) in addition to standard chemotherapy improves quality of life without affecting survival, in patients with advanced non-small-cell lung cancer: phase III results. Ann Oncol. 2004;15(6):906-14. doi:10.1093/annonc/mdh220.

135. Lowry CA, Hollis JH, de Vries A, Pan B, Brunet LR, Hunt JRF, et al. Identification of an immune-responsive mesolimbocortical serotonergic system: potential role in regulation of emotional behavior. Neuroscience. 2007;146(2):756-72. doi:10.1016/j.neuroscience.2007.01.067.

136. Matthews DM, Jenks SM. Ingestion of Mycobacterium vaccae decreases anxiety-related behavior and improves learning in mice. Behav Processes 2013:96:27-35. doi:10.1016/j.beproc.2013.02.007.

137. Bonjoch X, Ballesté E, Blanch AR. Multiplex PCR with $16 S$ rRNA genetargeted primers of Bifidobacterium spp. To identify sources of fecal pollution. Appl Environ Microbiol. 2004;70(5):3171-5. doi:10.1128/ aem.70.5.3171-3175.2004

138. Savignac HM, Tramullas M, Kiely B, Dinan TG, Cryan JF. Bifidobacteria modulate cognitive processes in an anxious mouse strain. Behav Brain Res. 2015;287:59-72. doi:10.1016/j.bbr.2015.02.044.

139. Savignac HM, Kiely B, Dinan TG, Cryan JF. Bifidobacteria exert strain-specific effects on stress-related behavior and physiology in BALB/C mice. Neurogastroenterol Motil. 2014;26(11):1615-27. doi:10.1111/nmo.12427.

140. Desbonnet L, Garrett L, Clarke G, Kiely B, Cryan JF, Dinan TG. Effects of the probiotic Bifidobacterium infantis in the maternal separation model of depression. Neuroscience. 2010;170(4):1179-88. doi:10.1016/ j.neuroscience.2010.08.005

141. Messaoudi M, Violle N, Bisson J-F, Desor D, Javelot H, Rougeot C. Beneficial psychological effects of a probiotic formulation (Lactobacillus helveticus R0052 and Bifidobacterium longum R0175) in healthy human volunteers. Gut Microbes. 2011;2(4):256-61. doi:10.4161/gmic.2.4.16108.

142. Messaoudi M, Lalonde $R$, Violle $N$, Javelot $H$, Desor D, Nejid A, et al. Assessment of psychotropic-like properties of a probiotic formulation (Lactobacillus helveticus R0052 and Bifidobacterium longum R0175) in rats and human subjects. Br J Nutr. 2011;105(05):755-64.

143. Bercik P, Park AJ, Sinclair D, Khoshdel A, Lu J, Huang $X$, et al. The anxiolytic effect of Bifidobacterium longum NCC3001 involves vagal pathways for gut-brain communication. Neurogastroenterol Motil. 2011;23(12):1132-9. doi:10.1111/j.1365-2982.2011.01796.x.
144. Bercik P, Verdu EF, Foster JA, Macri J, Potter M, Huang X, et al. Chronic gastrointestinal inflammation induces anxiety-like behavior and alters central nervous system biochemistry in mice. Gastroenterology. 2010;139(6):2102-2112.e1. doi:10.1053/j.gastro.2010.06.063.

145. Hong P-Y, Wu J-H, Liu W-T. Relative abundance of Bacteroides spp. in stools and wastewaters as determined by hierarchical oligonucleotide primer extension. Appl Environ Microbiol. 2008;74(9):2882-93. doi:10.1128/ aem.02568-07.

146. Hsiao Elaine Y, McBride Sara W, Hsien S, Sharon G, Hyde Embriette R, McCue T, et al. Microbiota modulate behavioral and physiological abnormalities associated with neurodevelopmental disorders. Cell. 2013;155(7):1451-63. doi:10.1016/j.cell.2013.11.024.

147. Yang H, Zhao X, Tang S, Huang H, Zhao X, Ning Z, et al. Probiotics reduce psychological stress in patients before laryngeal cancer surgery. Asia Pac J Clin Oncol. 2014; doi:10.1111/ajco.12120.

148. Castillo-Rojas G, Mazari-Hiríart M, Ponce de León S, Amieva-Fernández RI, Agis-Juárez RA, Huebner J, et al. Comparison of enterococcus faecium and enterococcus faecalis strains isolated from water and clinical samples: antimicrobial susceptibility and genetic relationships. PLoS One 2013;8(4):e59491. doi:10.1371/journal.pone.0059491.

149. Divyashri G, Krishna G, Muralidhara M, Prapulla SG. Probiotic attributes, antioxidant, anti-inflammatory and neuromodulatory effects of probiotic Enterococcus faecium CFR 3003: in vitro and in vivo evidences. J Med Microbiol. 2015;7(10):000184. doi:10.1099/jmm.0.000184.

150. Bernardeau M, Guguen M, Vernoux JP. Beneficial lactobacilli in food and feed: long-term use, biodiversity and proposals for specific and realistic safety assessments. FEMS Microbiol Rev. 2006;30(4):487-513. doi:10.1111/ j.1574-6976.2006.00020.x.

151. Flores GE, Bates ST, Knights D, Lauber CL, Stombaugh J, Knight R, et al. Microbial biogeography of public restroom surfaces. PLoS One. 2011;6(11):e28132. doi:10.1371/journal.pone.0028132.

152. Rao A, Bested A, Beaulne T, Katzman M, lorio C, Berardi J, et al. A randomized, double-blind, placebo-controlled pilot study of a probiotic in emotional symptoms of chronic fatigue syndrome. Gut Pathogens. 2009;1(1):1-6. doi:10.1186/1757-4749-1-6.

153. Benton D, Williams C, Brown A. Impact of consuming a milk drink containing a probiotic on mood and cognition. Eur J Clin Nutr. 2006;61(3):355-61.

154. Vitali B, Minervini G, Rizzello CG, Spisni E, Maccaferri S, Brigidi P, et al. Nove probiotic candidates for humans isolated from raw fruits and vegetables. Food Microbiol. 2012;31(1):116-25. doi:10.1016/j.fm.2011.12.027.

155. Schillinger $U$, Holzapfel W. The genus Lactobacillus. In: The genera of lactic acid bacteria. New York: Springer; 1995. p. 19-54.

156. Hewitt KM, Gerba CP, Maxwell SL, Kelley ST. Office space bacterial abundance and diversity in three metropolitan areas. PLoS One 2012;7(5):e37849. doi:10.1371/journal.pone.0037849.

157. Wang T, Hu X, Liang S, Li W, Wu X, Wang L, et al. Lactobacillus fermentum NS9 restores the antibiotic induced physiological and psychological abnormalities in rats. Benefic Microbes. 2015;6(5):707-17. doi:10.3920/BM2014.0177.

158. Luo J, Wang T, Liang S, Hu X, Li W, Jin F. Ingestion of Lactobacillus strain reduces anxiety and improves cognitive function in the hyperammonemia rat. Sci China Life Sci. 2014;57(3):327-35. doi:10.1007/s11427-014-4615-4.

159. Liang S, Wang T, Hu X, Luo J, Li W, Wu X, et al. Administration of Lactobacillus helveticus NS8 improves behavioral, cognitive, and biochemical aberrations caused by chronic restraint stress. Neuroscience. 2015;310:561-77. doi:10.1016/j.neuroscience.2015.09.033.

160. Ohland CL, Kish L, Bell H, Thiesen A, Hotte N, Pankiv E, et al. Effects of Lactobacillus helveticus on murine behavior are dependent on diet and genotype and correlate with alterations in the gut microbiome. Psychoneuroendocrinology. 2013;38(9):1738-47. doi:10.1016/ j.psyneuen.2013.02.008.

161. Smith CJ, Emge JR, Berzins K, Lung L, Khamishon R, Shah P, et al. Probiotics normalize the gut-brain-microbiota axis in immunodeficient mice. Am J Physiol Gastrointest Liver Physiol. 2014;307(8):4. doi:10.1152/ajpgi.00238.2014.

162. Woo J-Y, Gu W, Kim K-A, Jang S-E, Han MJ, Kim D-H. Lactobacillus pentosus var. plantarum C29 ameliorates memory impairment and inflammaging in a d-galactose-induced accelerated aging mouse model. Anaerobe. 2014;27:22-6. doi:10.1016/j.anaerobe.2014.03.003.

163. Tubelius P, Stan V, Zachrisson A. Increasing work-place healthiness with the probiotic lactobacillus reuteri: a randomised, double-blind placebocontrolled study. Environ Health. 2005;4(1):25. 
164. Gareau MG, Wine E, Rodrigues DM, Cho JH, Whary MT, Philpott DJ, et al. Bacterial infection causes stress-induced memory dysfunction in mice. Gut. 2010;60(3):307-17. doi:10.1136/gut.2009.202515.

165. Steenbergen L, Sellaro R, van Hemert S, Bosch JA, Colzato LS. A randomized controlled trial to test the effect of multispecies probiotics on cognitive reactivity to sad mood. Brain Behav Immun. 2015;48:258-64. doi:10.1016/ j.bbi.2015.04.003.

166. Tillisch K, Labus J, Kilpatrick L, Jiang Z, Stains J, Ebrat B, et al. Consumption of fermented milk product with probiotic modulates brain activity. Gastroenterology. 2013;144(7):1394-401.e4. doi:10.1053/j.gastro.2013.02.043.

167. Mohammadi AA, Jazayeri S, Khosravi-Darani K, Solati Z, Mohammadpour N, Asemi $Z$ et al. The effects of probiotics on mental health and hypothalamic-pituitary-adrenal axis: a randomized, double-blind, placebocontrolled trial in petrochemical workers. Nutr Neurosci. doi:10.1179/ $1476830515 Y .0000000023$.

168. D'Mello C, Ronaghan N, Zaheer R, Dicay M, Le T, MacNaughton WK, et al. Probiotics improve inflammation-associated sickness behavior by altering communication between the peripheral immune system and the brain. J Neurosci. 2015;35(30):10821-30

169. Jeong J, Kim K, Ahn Y, Sim J, Woo J, Huh C, et al. Probiotic mixture KF attenuates age-dependent memory deficit and lipidemia in Fischer 344 rats. J Microbiol Biotechnol. 2015;25(9):1532-6. doi:10.4014/jmb.1505.05002.

170. Davari S, Talaei SA, Alaei H, Salami M. Probiotics treatment improves diabetes-induced impairment of synaptic activity and cognitive function: behavioral and electrophysiological proofs for microbiome-gut-brain axis. Neuroscience. 2013;240:287-96. doi:10.1016/..neuroscience.2013.02.055.

171. Gilbert K, Arseneault-Bréard J, Flores Monaco F, Beaudoin A, Bah TM, Tompkins TA, et al. Attenuation of post-myocardial infarction depression in rats by $\mathrm{n}-3$ fatty acids or probiotics starting after the onset of reperfusion. $\mathrm{Br}$ J Nutr. 2013;109(01):50-6. doi:10.1017/50007114512003807.

\section{Submit your next manuscript to BioMed Central and take full advantage of:}

- Convenient online submission

- Thorough peer review

- No space constraints or color figure charges

- Immediate publication on acceptance

- Inclusion in PubMed, CAS, Scopus and Google Scholar

- Research which is freely available for redistribution 